\title{
Review
}

Obesity and Metabolic Syndrome

Diabetes Metab J 2019;43:752-762

https://doi.org/10.4093/dmj.2019.0174

pISSN 2233-6079 · eISSN 2233-6087

DIABET\&S \& METABOLISM JOURNAL

\section{Two Faces of White Adipose Tissue with Heterogeneous Adipogenic Progenitors}

\author{
Injae Hwang, Jae Bum Kim \\ National Creative Research Initiatives Center for Adipose Tissue Remodeling, Institute of Molecular Biology and Genetics, Department of Biological Sciences, \\ Seoul National University, Seoul, Korea
}

Chronic energy surplus increases body fat, leading to obesity. Since obesity is closely associated with most metabolic complications, pathophysiological roles of adipose tissue in obesity have been intensively studied. White adipose tissue is largely divided into subcutaneous adipose tissue (SAT) and visceral adipose tissue (VAT). These two white adipose tissues are similar in their appearance and lipid storage functions. Nonetheless, emerging evidence has suggested that SAT and VAT have different characteristics and functional roles in metabolic regulation. It is likely that there are intrinsic differences between VAT and SAT. In diet-induced obese animal models, it has been reported that adipogenic progenitors in VAT rapidly proliferate and differentiate into adipocytes. In obesity, VAT exhibits elevated inflammatory responses, which are less prevalent in SAT. On the other hand, SAT has metabolically beneficial effects. In this review, we introduce recent studies that focus on cellular and molecular components modulating adipogenesis and immune responses in SAT and VAT. Given that these two fat depots show different functions and characteristics depending on the nutritional status, it is feasible to postulate that SAT and VAT have different developmental origins with distinct adipogenic progenitors, which would be a key determining factor for the response and accommodation to metabolic input for energy homeostasis.

Keywords: Adipogenesis; Adipose tissue; Energy metabolism; Inflammation; Obesity; Stem cells

\section{FAT DEPOT-SPECIFIC REGULATION OF ENERGY METABOLISM}

Energy metabolism is crucial for the survival of living organisms. Metabolic homeostasis is tightly controlled by multiple endogenous and exogenous regulators [1-6]. Recently, accumulating evidence has suggested that adipose tissue is important for energy balance and endocrine functions by secreting various signaling molecules including adipokines, cytokines and lipokines [7-11]. In mammals, adipose tissue is spread throughout the body and is largely divided into white adipose tissue and brown adipose tissue which have their own functions (Fig. 1A). Brown adipose tissue plays a key role in maintaining core body temperature by heat generation through un- coupling protein-1 (UCP-1) [12-14]. Since brown adipose tissue burns carbohydrates and lipid metabolites to produce heat, it has been recently considered as a potential target to treat obesity and metabolic complications. However, we will not consider brown and beige adipose tissue, which have been addressed in numerous other review papers. Instead, we will focus on heterogeneous characters of white adipose tissue in this review [12,15-17]. Unlike brown adipose tissue, white adipose tissue is a prominent energy reservoir and can be anatomically categorized into subcutaneous adipose tissue (SAT) and visceral adipose tissue (VAT) (Fig. 1A). SAT is localized under the dermal layers where it protects against physical damage and insulates the body from cold environments. VAT is located in the intra-abdominal cavity and is able to dynamically commu-
Corresponding author: Jae Bum Kim (D) https://orcid.org/0000-0003-2337-6935 Institute of Molecular Biology and Genetics, Department of Biological Sciences, Seoul National University, 1 Gwanak-ro, Gwanak-gu, Seoul 08826, Korea

E-mail: jaebkim@snu.ac.kr

Received: Sep. 20, 2019; Accepted: Oct. 28, 2019
This is an Open Access article distributed under the terms of the Creative Commons Attribution Non-Commercial License (http://creativecommons.org/licenses/by-nc/4.0/) which permits unrestricted non-commercial use, distribution, and reproduction in any medium, provided the original work is properly cited. 


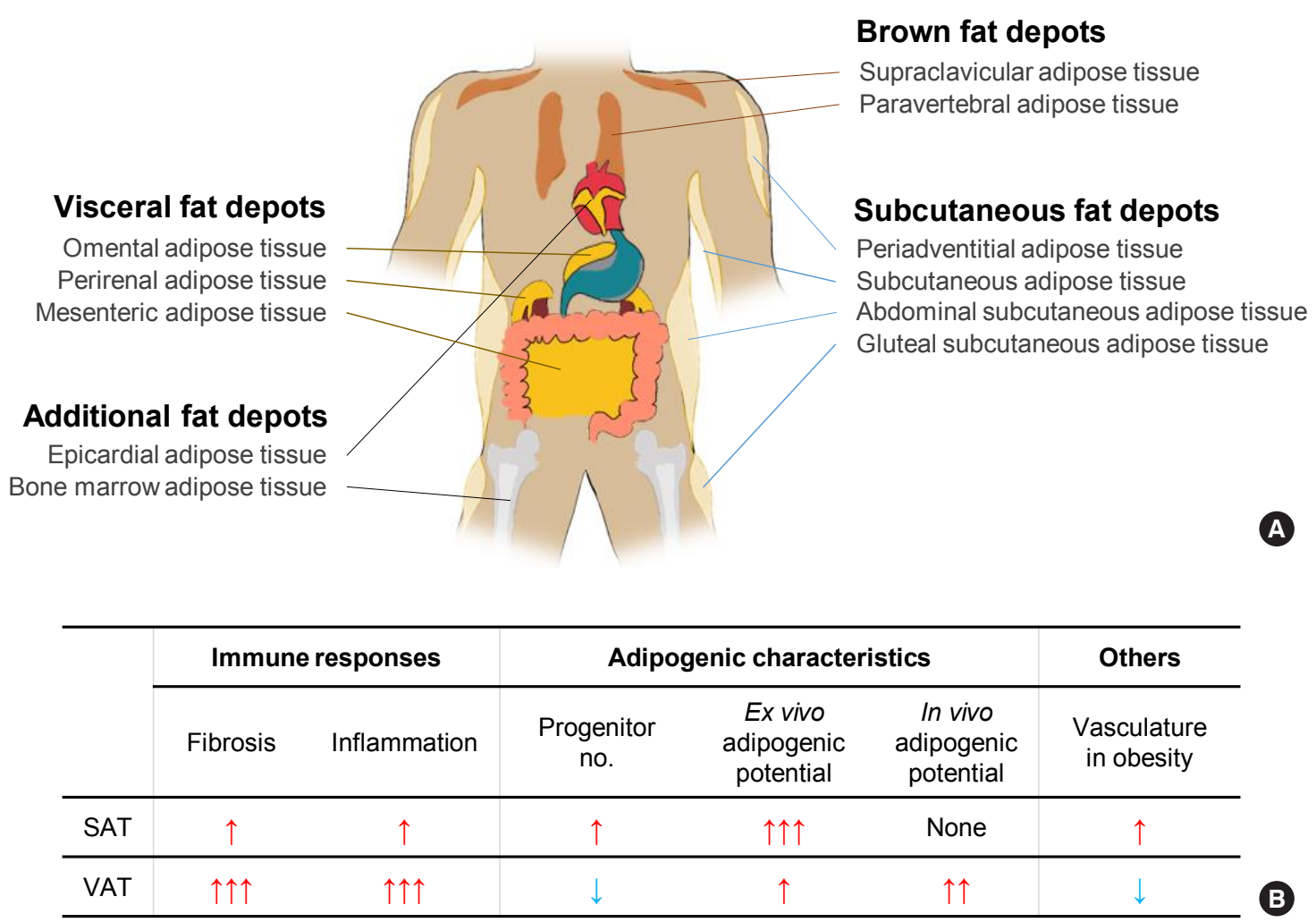

Fig. 1. Adipose tissue distribution in human and heterogeneous characteristics between subcutaneous adipose tissue (SAT) and visceral adipose tissue (VAT) in obese mice. (A) In human, adipose tissues are found in areas all over the body. In particular, brown adipose tissue is localized in neck, shoulder, and thorax to generate heat via higher activity of mitochondria and uncoupling protein-1 (UCP-1). VAT is localized in intra-abdomen and SAT is spread throughout the whole body. Both SAT and VAT have a higher capacity for lipid storage than brown adipose tissue. (B) In obese mice, SAT and VAT are differentially respond to obesity in many aspects such as immune responses, adipogenesis, and vasculatures. In obese mice, VAT exhibit elevated fibrosis and inflammatory responses accompanied with increased in vivo adipogenic potential. In contrast, such effects were rarely observed in obese SAT. Moreover, prolonged obesity reduces vasculature in obese VAT, whereas vasculature in obese SAT is denser than that in obese VAT.

nicate with other internal organs due to their physical proximity. Since both SAT and VAT are morphologically similar, it has been considered that SAT and VAT may have the same functions with similar or identical adipogenic progenitors (APs). It has been reported that both SAT and VAT appear to originate from myogenic factor $5\left(\mathrm{Myf5}^{-}\right)$mesenchymal/mesodermal cells during development $[18,19]$. Nonetheless, recent studies have shown that several characteristics of SAT and VAT are distinct in aspects of metabolic regulation (Figs. 1B and 2). For instance, in obese humans, expanded VAT is highly correlated with elevated susceptibility of metabolic disorders. However, this correlation is not observed in obese people with expanded SAT [20-22]. Moreover, it has been reported that metabolic parameters of obese patients with a higher proportion of SAT are closer to the normal range [23-25]. Although accumulating evidence suggests that metabolic characteristics between SAT and VAT are different [20,26-28], it is unclear whether distinct metabolic responses and regulation in VAT and SAT would be a simple correlation or causal relationship. To address this issue, rodent models including mice and rats have been subjected to be investigated. For example, fat tissue transplantation experiments in obese mice have provided direct evidence that SAT is metabolically beneficial. In obese mice, intra-abdominal transplantation of SAT downregulates body weight gain and ameliorates insulin resistance and glucose intolerance $[29,30]$. On the other hand, surgical removal of VAT alleviates metabolic complications in rat [31]. A very recent study reported that transplanted donor fat tissue from obese mice re- 

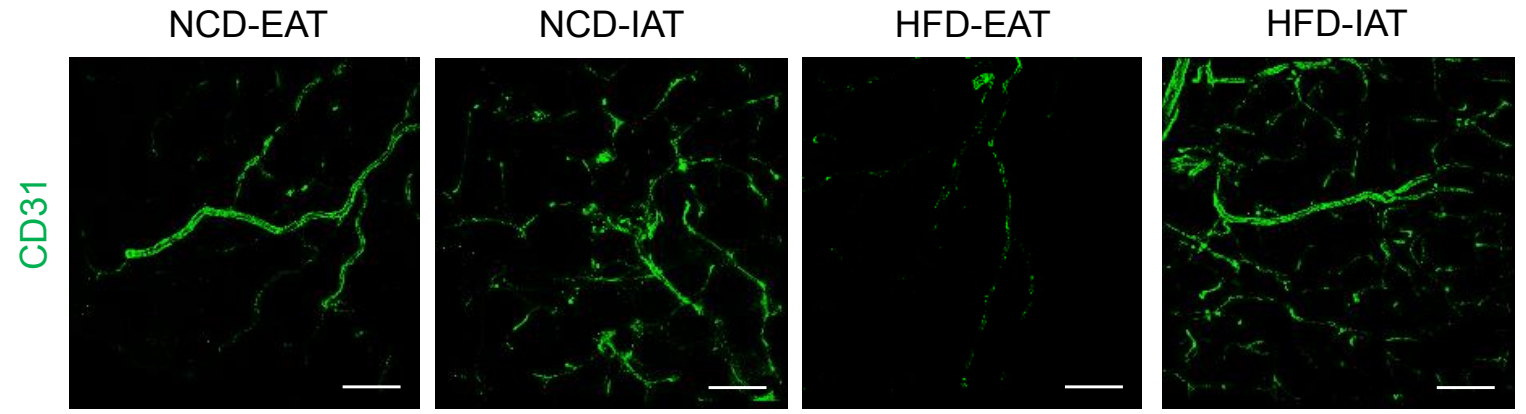

Fig. 2. Dissimilarity of vascularization and angiogenesis in subcutaneous adipose tissue (SAT) and visceral adipose tissue (VAT) upon high-fat diet (HFD) feeding. Endothelial cells were stained with CD31 antibody conjugated with fluorescein isothiocyanate (FITC) fluorescence. Upon HFD feeding, vascular structures of visceral epididymal adipose tissue (EAT) are dramatically reduced compared to normal chow diet (NCD) fed mice. However, subcutaneous inguinal adipose tissue (IAT) in obesity maintains a similar degree of vasculatures compared to IAT in NCD condition. Scale bar indicates $100 \mu \mathrm{m}$.

tain their intrinsic inflammatory characteristics in obese mice [32]. These collective findings have supported that SAT and VAT would have their own causal factor(s) to exhibit the different metabolic regulation.

\section{DIFFERENT ADIPOGENIC CHARACTERISTICS BETWEEN SAT AND VAT}

In adipose tissue, the adipogenic capacity from progenitor cells is closely associated with metabolic changes. In obesity, hypertrophic adipocytes (enlarged adipocytes) are frequently observed in VAT. These hypertrophic adipocytes contribute to systemic insulin resistance $[33,34]$. In contrast, small and multilocular adipocytes exhibit increased glucose-uptake upon exposure to insulin compared to hypertrophic and unilocular adipocytes [33,35]. Moreover, genetically obese mice that feature increased numbers of adipocytes (adipocyte hyperplasia) in SAT are relatively insulin sensitive and maintain a normal range of metabolic parameters [36]. Obese but metabolically healthy humans tend to be biased towards a higher proportion of SAT with enhanced adipocyte hyperplasia [23-25]. Consistently, in obese patients, increased adipogenesis due to treatment with the thiazolidinedione, a peroxisome proliferator-activated receptor $\gamma$ (PPAR $\gamma$ ) agonist, alleviates metabolic disorders by improving insulin sensitivity, accompanied with increased SAT [37-39].

By treating with collagenase, adipose tissue can be largely separated into differentiated adipocytes and stromal vascular cells (SVCs). SVCs are composed of heterogeneous cell populations including endothelial cells, immune cells, fibrocytes, and APs that can potentially differentiate into adipocytes in the presence of adipogenic stimuli, including insulin-like growth factor-1 and glucocorticoids [9,19]. Differentiation of APs into mature adipocytes is governed by key adipogenic transcription factors such as PPAR $\gamma$, CCAAT/enhancer binding proteins (C/ EBPs), and sterol-regulatory element binding protein $1 \mathrm{c}$ (SREBP1c) [40-43]. Fully differentiated adipocytes from SAT and VAT highly express adipogenic and lipogenic genes. Nonetheless, it seems that the adipogenic capacity differs between SAT and VAT in the presence of particular cues. APs isolated from SAT and VAT differ in their degree of adipocyte differentiation under adipogenic culture conditions [44,45]. Under ex vivo cell culture conditions, APs from SAT are more adipogenic than those from VAT [34]. Furthermore, obese patients treated with thiazolidinedione show expansion of SAT with hyperplasia of small adipocytes while VAT mass is relatively reduced $[37,38]$. The data from ex vivo cell culture conditions have been challenged by in vivo studies utilizing mouse lineage tracing systems $[46,47]$. Upon high-fat diet (HFD) feeding, the proliferation of APs from VAT is greatly increased within 3 days. These proliferating APs differentiate into adipocytes whereas APs from obese SAT do not rapidly proliferate [47]. The inconsistency between in vivo animal experimental data and ex vivo cell culture data make it plausible to speculate that the different adipogenic potentials of SAT and VAT could reflect either tissue environmental cues or intrinsically different characteristics of APs from each fat depot. In particular, given that comparisons of the adipogenic potential during $e x$ vivo cell culture excluding tissue environmental niche are different between SAT and VAT, it appears that APs from SAT 
and VAT could have their own intrinsic characteristics. Thus, it is possible that the developmental origins or ancestral cellular lineages of APs in SAT and VAT might not be the same population. For instance, it has been demonstrated that VAT is preferentially enriched with mesothelial APs $[48,49]$. On the other hand, there is a high abundance of APs that express dipeptidyl protease 4 (DPP4) in SAT [50]. Moreover, recent studies with single cell RNA-seq analysis from stromal cells without immune and endothelial cells have shown that APs of SAT and VAT would have different transcriptomic features [50-52]. These recent findings indicate that developmentally different adipogenic potentials in SAT and VAT would be one of the key intrinsic factors to determine its own roles on metabolic regulation in obesity.

\section{IMMUNOMODULATORY ROLES OF DEPOT- SPECIFIC AP IN SAT AND VAT}

In the early 1990s, it was reported that the tumor necrosis factor $\alpha$, an inflammatory cytokine, is synthesized and secreted in adipose tissue [53]. This finding prompted the investigation of inflammatory responses in adipose tissue due to their strong association with metabolic dysregulation in obesity (Fig. 3) [7,54-56]. In lean fat tissue, anti-inflammatory cells such as regulatory T-cells, eosinophils, and invariant natural killer $\mathrm{T}$ (iNKT) cells play crucial roles to maintain adipose tissue ho- meostasis [57-65]. In obese adipose tissue, various pro-inflammatory immune cells such as macrophages, neutrophils, cytotoxic T cells, and B cells are recruited and prevail against antiinflammatory cells to increase pro-inflammatory responses in obesity [27,66-70]. Elevated inflammatory responses by proinflammatory immune cells disrupt metabolic homeostasis by augmenting fibrosis, oxidative stress, and insulin resistance in obese adipose tissue [71-75]. Moreover, pro-inflammatory immune cells not only impair insulin signaling, but also dysregulate normal lipid metabolism in obesity $[66,76]$. Of note, VAT is prone to be pro-inflammatory, whereas SAT is less susceptible to inflammatory responses in obesity (Fig. 4) [27,77]. In a mouse model, macrophage infiltration is rapidly increased in VAT upon HFD feeding [78]. However, such effects are rarely observed in obese SAT $[26,27,32,79]$. It has been proposed that certain cell types in adipose SVCs in obese VAT contribute to the aggravation of pro-inflammation. In obese VAT, increased fibrosis interrupts normal metabolic functions and elevates inflammatory responses $[71,80]$. Moreover, it has been reported that adipose tissue fibrosis induced by obesity is mediated by APs expressing both platelet-derived growth factor receptor $\alpha$ (PDGFR $\alpha$ ) and high level of cluster of differentiation 9 (CD9) $[81,82]$. Although these fibrotic APs still express AP marker genes such as CD34, stem cell antigen-1 (Sca-1), and PDGFRs, their adipogenic potential is diminished $[82,83]$. Furthermore, these obesity-induced fibrotic APs stimulate expressions of
Normal adipose tissue

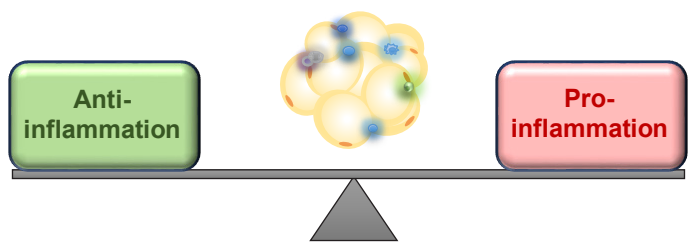

Anti-inflammatory cells

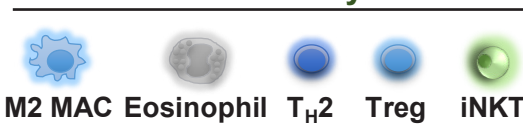

Obese adipose tissue

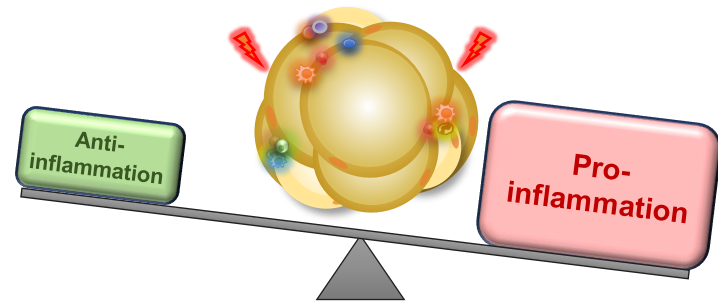

Pro-inflammatory cells

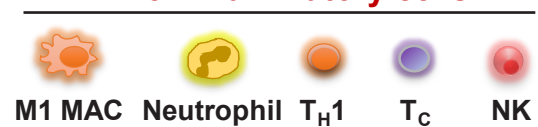

Fig. 3. Immune cells and pro-inflammatory responses in obesity. Normal and healthy adipose tissue harbors various types of antiinflammatory immune cells such as M2-like macrophages (M2 MAC), eosinophils, helper T type 2 ( $\mathrm{T}_{\mathrm{H}} 2$ ) cells, regulatory T (Treg) cells, and invariant natural killer T (iNKT) cells. These immune cells are involved in maintaining normal adipose functions and insulin sensitivity. In obesity, the number of pro-inflammatory immune cells including neutrophil, M1-like macrophages (M1 MAC), neutrophils, helper T type $1\left(\mathrm{~T}_{\mathrm{H}} 1\right)$ cells, Cytotoxic $\mathrm{T}(\mathrm{Tc})$ cells, and natural killer $(\mathrm{NK})$ cells are elevated. In parallel, anti-inflammatory immune cells are decreased, leading to aggravation of adipose tissue inflammation and adipose dysfunction. 


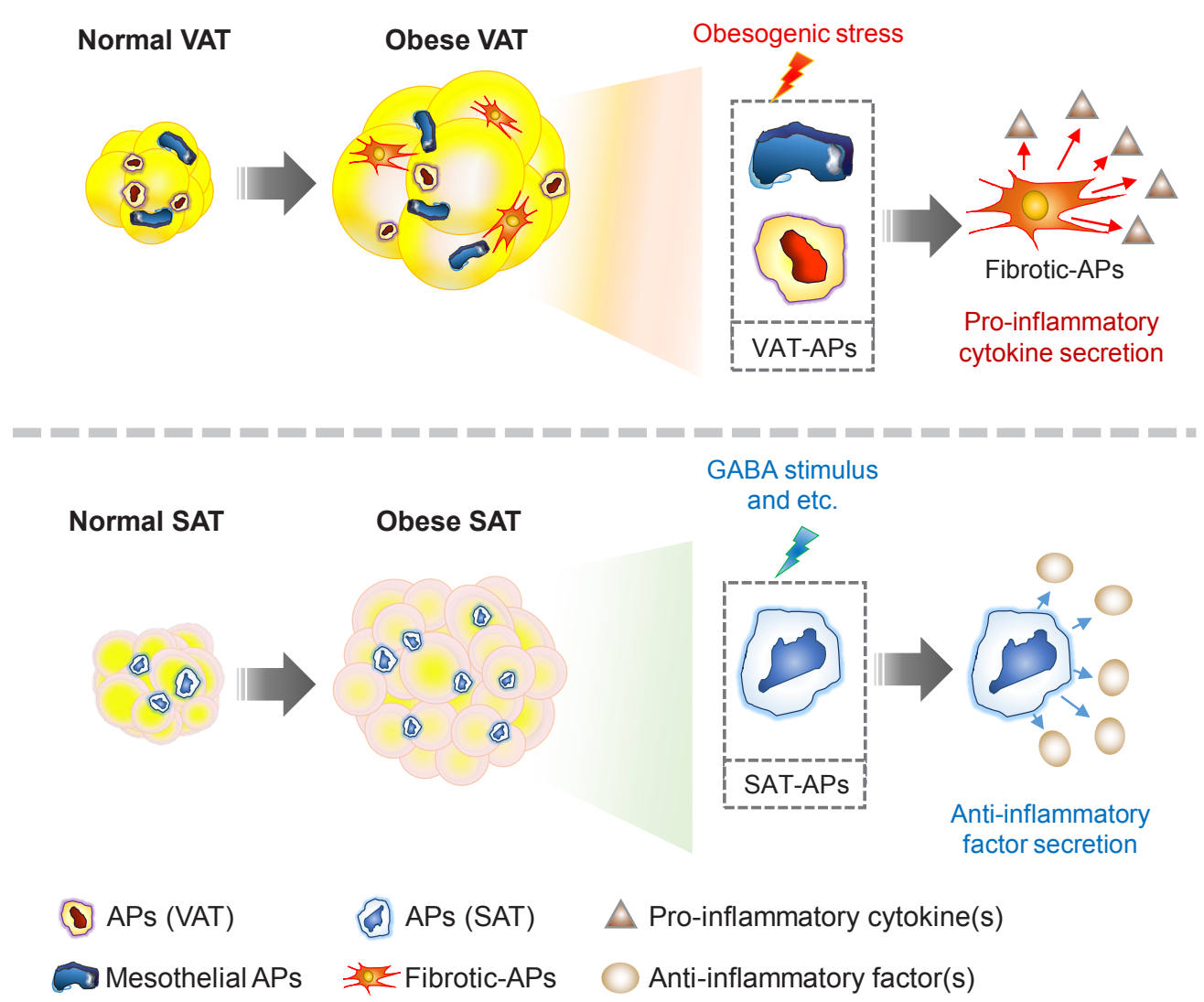

Fig. 4. Subcutaneous and visceral adipogenic progenitors (APs) differentially respond to obesity and exert opposite effects on adipose tissue inflammation. Visceral APs are composed of mesothelial and mesodermal cells, but a certain portion of these cells lose adipogenic potential and are transformed into pro-inflammatory fibrocytes in obesity. The fibrotic-APs in visceral adipose tissue (VAT) exacerbate adipose tissue inflammation via inducing fibrosis and secreting pro-inflammatory cytokines. On the other hand, subcutaneous APs suppress pro-inflammatory macrophage infiltration into subcutaneous adipose tissue (SAT) in response to gamma-aminobutyric acid (GABA). Consequently, these anti-inflammatory effects on SAT would contribute to improvement of energy metabolism in obesity.

pro-inflammatory genes and inhibit adipogenesis in VAT [83]. These results imply that APs in obese VAT would contribute to aggravation of adipose tissue dysfunction and metabolic dysregulation. On the other hand, the number of these cell populations in SAT are significantly lower than VAT [32]. In addition, intra-abdominal transplantation of SAT alleviates systemic inflammatory responses and insulin resistance in obese mice $[30,32]$, implying that certain factors of SAT have anti-inflammatory roles in obesity. Furthermore, it has been shown that gamma-aminobutyric acid (GABA) signaling in SAT is crucial in suppressing SAT inflammation in obesity [32]. GABA is an inhibitory neurotransmitter in the central nervous system $[84,85]$. Although GABA concentration in peripheral tissues is lower than in the central nervous system, SAT is able to synthesize and stabilize GABA (approximately 5 to $20 \mathrm{nmol} / \mathrm{g}$ tis- sue) compared to VAT [32]. More importantly, it has been demonstrated that the anti-inflammatory cell type responding to GABA is APs rather than other immune cells, in SAT [32]. Although the underlying mechanisms by which APs from SAT and VAT could differentially regulate fat depot-specific inflammatory responses in obesity are still unclear, these findings open the door to emphasize fat depot-specific and immunomodulatory roles of APs in the regulation of energy metabolism in obesity.

\section{FAT DEPOT-SELECTIVE HETEROGENEOUS AP AND THEIR MARKERS}

In mammalian development, adipocytes are derived from mesenchyme/mesoderm [19]. Although bone marrow has 
Table 1. A list of surface marker genes identified for APs

\begin{tabular}{|c|c|c|c|}
\hline Gene & Discovery and identification & Remark & Reference \\
\hline CD10/NEP/cALLA & $\begin{array}{l}\text { Hematopoietic stem cells and } \\
\text { mesenchymal tumour cells }\end{array}$ & $\begin{array}{l}\text { Alternative marker for mesenchymal } \\
\text { stem cells }\end{array}$ & $\begin{array}{l}\text { Br J Haematol 1994;87:655-7 } \\
\text { Arthritis Rheum 2002;46:3349-60 } \\
\text { Ann N Y Acad Sci 2007;1106:262-71 } \\
\text { Mod Pathol 2002;15:923-30 }\end{array}$ \\
\hline CD73/NT5E & Placenta & Mesenchymal stem cell marker & $\begin{array}{l}\text { Eur J Biochem 1990;191:563-9 } \\
\text { Cytotherapy 2006;8:315-7 }\end{array}$ \\
\hline CD90/Thy-1 & Thymocytes & $\begin{array}{l}\text { Mesenchymal and hematopoietic stem } \\
\text { cell marker }\end{array}$ & $\begin{array}{l}\text { J Exp Med 1964;120:413-33 } \\
\text { Am J Physiol Gastrointest Liver Physiol } \\
\text { 2006;291:G45-54 }\end{array}$ \\
\hline CD105/Endoglin & Mesenchymal stem cells & Mesenchymal stem cell marker & Biochem Biophys Res Commun 1999;265:134-9 \\
\hline CD31/PECAM-1 & Endothelial cells & $\begin{array}{l}\text { Negative surface marker staining } \\
\text { endothelial cell }\end{array}$ & $\begin{array}{l}\text { Science 1990;247:1219-22 } \\
\text { Cell 2008;135:240-9 }\end{array}$ \\
\hline CD45/LCA & Hematopoietic stem cells & $\begin{array}{l}\text { Negative surface marker staining } \\
\text { hematopoietic immune cells }\end{array}$ & $\begin{array}{l}\text { Annu Rev Immunol 2003;21:107-37 } \\
\text { Science 2008;322:583-6 } \\
\text { Cell 2008;135:240-9 }\end{array}$ \\
\hline Ter119/Ly-76 & Bone marrow cells & $\begin{array}{l}\text { Negative surface marker staining } \\
\text { hematopoietic immune cells }\end{array}$ & $\begin{array}{l}\text { Cell 1990;62:863-74 } \\
\text { Blood 2000;95:2559-68 } \\
\text { Diabetes 2012;61:1691-9 } \\
\text { Science 2008;322:583-6 }\end{array}$ \\
\hline CD34 & Hematopoietic stem cells & $\begin{array}{l}\text { AP marker, but not mesenchymal stem } \\
\text { cell marker }\end{array}$ & $\begin{array}{l}\text { J Immunol 1992;148:267-71 } \\
\text { Cell 2008;135:240-9 } \\
\text { Science 2008;322:583-6 }\end{array}$ \\
\hline Sca-1/Ly6a & Hematopoietic stem cells & AP marker & $\begin{array}{l}\text { Mol Cell Biol 1990;10:5150-9 } \\
\text { Cell 2008;135:240-9 } \\
\text { Science 2008;322:583-6 }\end{array}$ \\
\hline PDGFRa & APs & AP marker & $\begin{array}{l}\text { Cell Metab 2012;15:480-91 } \\
\text { Cell Metab 2013;18:355-67 }\end{array}$ \\
\hline PDGFR $\beta$ & Perivascular cells & AP marker & $\begin{array}{l}\text { Science 2008;322:583-6 } \\
\text { Elife 2018;7:e39636 }\end{array}$ \\
\hline $\mathrm{CD} 24$ & Adipose stromal cells & AP marker & Cell 2008;135:240-9 \\
\hline DPP4 & Adipose stromal cells & Progenitor cell type marker of AP & Science 2019;364:eaav2501 \\
\hline ICAM-1 & Adipose stromal cells & AP marker & Science 2019;364:eaav2501 \\
\hline
\end{tabular}

CD10, cluster of differentiation 10; NEP, neutral endopeptidase; cALLA, common acute lymphoblastic leukemiaantigen; NT5E, ecto-5' nucleotidase; Thy-1, thymus cell antigen 1; PECAM-1, platelet endothelial cell adhesion molecule 1; LCA, leukocyte common antigen; Ly-76, lymphocyte antigen-76; AP, adipogenic progenitor; Sca-1, stem cell antigen 1; Ly6a, lymphocyte antigen-6a; PDGFR, platelet-derived growth factor receptor; DPP4, dipeptidyl protease 4; ICAM-1, intercellular adhesion molecule-1.

been reported as a source of APs due to its enriched pools of mesenchymal stem cells [86], recent in vivo mouse lineage tracing systems have revealed that APs in adult animals reside in the adipose perivascular region [45,46]. Several groups have reported that numerous genes such as $\mathrm{CD} 31, \mathrm{CD} 45$, leukocyte antigen 76/TER-119, PDGFR $\alpha$, PDGFR $\beta$, CD24, CD34, Sca1, DPP4, and intercellular adhesion molecule-1 (ICAM-1), are potential surface markers for APs (Table 1) [44,45,50,52,8789]. However, several lines of evidence have suggested that the surface marker genes mentioned above are insufficient to pinpoint or isolate pure APs. Firstly, fibrotic APs still express adipogenic surface markers despite the loss of their potential to differentiate into adipocytes $[81,82,90]$. Secondly, APs isolated from SAT and VAT using aforementioned surface markers show different functional outcomes in many aspects that include fibrosis, adipogenesis, vascularization, and inflammation $[32,50,51,91,92]$. Moreover, single cell RNA sequencing analyses has shown that isolated APs with adipogenic surface mark- 
ers exhibit heterogeneous cell populations in different white adipose tissues $[51,52,83]$. In particular, single-cell transcriptome features of APs from SAT are different from VAT. It has been recently reported that SAT has more abundant DPP4 positive APs than VAT [50]. Due to their multipotency, it has been proposed that DPP4 positive APs could be a progenitor cell type of ICAM-1 or CD142 positive APs which are more committed cell type of APs. Nevertheless, the adipogenic potential of CD142 positive AP is still controversial [52]. For example, it has been shown that CD142 and ATP-binding cassette subfamily G (ABCG1) double-positive stromal cell is a suppressive cell type of adipogenesis [52]. Thus, further studies are evidently needed to identify more precise cellular markers to elucidate fat depot-specific roles from various subpopulations of APs.

\section{CONCLUSIONS}

In this review, we have discussed that several white adipose tissues have distinct characteristics depending on their anatomical locations and differential responses to nutritional status. Depending on the anatomical location of adipose tissue, adipogenesis relies on the tissue niche, whereas differential immune responses between fat depots are affected by intrinsic characteristics, rather than by environmental factors [32,89]. Accumulating data from latest technologies including singlecell RNA sequencing analyses and lineage tracing mouse models have shown that APs from SAT and VAT have distinct and heterogeneous gene expression profiles. Moreover, it is very likely that APs from SAT and VAT mediate different adipogenic and immunomodulatory functions in obesity. APs from VAT are more adipogenic and pro-inflammatory whereas APs from SAT have more progenitor cell types of APs (DPP4 ${ }^{+} \mathrm{APs}$ ) and are anti-inflammatory. These differences in SAT and VAT could differentially contribute to metabolic regulation, indicating that APs would be one of the key factors in fat tissue development and whole body metabolism. According to these heterogeneities between SAT and VAT, it is feasible to assume that subcutaneous and visceral APs would have different developmental origins despite their similarities in tissue morphology. Taken together, understanding fat depot-specific adipogenesis and relationship between APs and adipose tissue immunity will shed new light on metabolic and stem cell research area in the future.

\section{CONFLICTS OF INTEREST}

No potential conflict of interest relevant to this article was reported.

\section{ORCID}

Injae Hwang https://orcid.org/0000-0003-1130-1231

Jae Bum Kim https://orcid.org/0000-0003-2337-6935

\section{ACKNOWLEDGMENTS}

This work was supported by the National Creative Research Initiative Program (2011-0018312) and by the Ministry of Science, ICT \& Future Planning (MSIP). Injae Hwang was supported by the BK21 program and Hi Seoul Science (Humanities) Fellowship funded by the Seoul Scholarship Foundation.

\section{REFERENCES}

1. Bechmann LP, Hannivoort RA, Gerken G, Hotamisligil GS, Trauner M, Canbay A. The interaction of hepatic lipid and glucose metabolism in liver diseases. J Hepatol 2012;56:952-64.

2. Petersen KF, Dufour S, Savage DB, Bilz S, Solomon G, Yonemitsu S, Cline GW, Befroy D, Zemany L, Kahn BB, Papademetris X, Rothman DL, Shulman GI. The role of skeletal muscle insulin resistance in the pathogenesis of the metabolic syndrome. Proc Natl Acad Sci U S A 2007;104:12587-94.

3. Backhed F, Ding H, Wang T, Hooper LV, Koh GY, Nagy A, Semenkovich CF, Gordon JI. The gut microbiota as an environmental factor that regulates fat storage. Proc Natl Acad Sci U S A 2004;101:15718-23.

4. Hwang I, Park YJ, Kim YR, Kim YN, Ka S, Lee HY, Seong JK, Seok YJ, Kim JB. Alteration of gut microbiota by vancomycin and bacitracin improves insulin resistance via glucagon-like peptide 1 in diet-induced obesity. FASEB J 2015;29:2397-411.

5. Cota D, Proulx K, Smith KA, Kozma SC, Thomas G, Woods SC, Seeley RJ. Hypothalamic mTOR signaling regulates food intake. Science 2006;312:927-30.

6. Schwartz MW, Seeley RJ, Campfield LA, Burn P, Baskin DG. Identification of targets of leptin action in rat hypothalamus. J Clin Invest 1996;98:1101-6.

7. Choe SS, Huh JY, Hwang IJ, Kim JI, Kim JB. Adipose tissue remodeling: its role in energy metabolism and metabolic disorders. Front Endocrinol (Lausanne) 2016;7:30. 
8. Cao H. Adipocytokines in obesity and metabolic disease. J Endocrinol 2014;220:T47-59.

9. Rosen ED, MacDougald OA. Adipocyte differentiation from the inside out. Nat Rev Mol Cell Biol 2006;7:885-96.

10. Lynes MD, Leiria LO, Lundh M, Bartelt A, Shamsi F, Huang TL, Takahashi H, Hirshman MF, Schlein C, Lee A, Baer LA, May FJ, Gao F, Narain NR, Chen EY, Kiebish MA, Cypess AM, Bluher M, Goodyear LJ, Hotamisligil GS, Stanford KI, Tseng YH. The cold-induced lipokine 12,13-diHOME promotes fatty acid transport into brown adipose tissue. Nat Med 2017;23:6317.

11. Cao H, Gerhold K, Mayers JR, Wiest MM, Watkins SM, Hotamisligil GS. Identification of a lipokine, a lipid hormone linking adipose tissue to systemic metabolism. Cell 2008;134:93344.

12. Van Marken Lichtenbelt WD, Vanhommerig JW, Smulders NM, Drossaerts JM, Kemerink GJ, Bouvy ND, Schrauwen P, Teule GJ. Cold-activated brown adipose tissue in healthy men. N Engl J Med 2009;360:1500-8.

13. Lowell BB, S-Susulic V, Hamann A, Lawitts JA, Himms-Hagen J, Boyer BB, Kozak LP, Flier JS. Development of obesity in transgenic mice after genetic ablation of brown adipose tissue. Nature 1993;366:740-2.

14. Seale P, Kajimura S, Spiegelman BM. Transcriptional control of brown adipocyte development and physiological function: of mice and men. Genes Dev 2009;23:788-97.

15. Cannon B, Nedergaard J. Brown adipose tissue: function and physiological significance. Physiol Rev 2004;84:277-359.

16. Bartelt A, Heeren J. Adipose tissue browning and metabolic health. Nat Rev Endocrinol 2014;10:24-36.

17. Ikeda K, Maretich P, Kajimura S. The common and distinct features of brown and beige adipocytes. Trends Endocrinol Metab 2018;29:191-200.

18. Tseng YH, Cypess AM, Kahn CR. Cellular bioenergetics as a target for obesity therapy. Nat Rev Drug Discov 2010;9:465-82.

19. Gesta S, Tseng YH, Kahn CR. Developmental origin of fat: tracking obesity to its source. Cell 2007;131:242-56.

20. Vague J. The degree of masculine differentiation of obesities: a factor determining predisposition to diabetes, atherosclerosis, gout, and uric calculous disease. Am J Clin Nutr 1956;4:20-34.

21. Coutinho T, Goel K, Correa de Sa D, Kragelund C, Kanaya AM, Zeller M, Park JS, Kober L, Torp-Pedersen C, Cottin Y, Lorgis L, Lee SH, Kim YJ, Thomas R, Roger VL, Somers VK, Lopez-Jimenez F. Central obesity and survival in subjects with coronary artery disease: a systematic review of the literature and collaborative analysis with individual subject data. J Am Coll Cardiol 2011;57:1877-86.

22. Bray GA, Jablonski KA, Fujimoto WY, Barrett-Connor E, Haffner S, Hanson RL, Hill JO, Hubbard V, Kriska A, Stamm E, PiSunyer FX; Diabetes Prevention Program Research Group. Relation of central adiposity and body mass index to the development of diabetes in the Diabetes Prevention Program. Am J Clin Nutr 2008;87:1212-8.

23. Sims EA. Are there persons who are obese, but metabolically healthy? Metabolism 2001;50:1499-504.

24. Samocha-Bonet D, Dixit VD, Kahn CR, Leibel RL, Lin X, Nieuwdorp M, Pietilainen KH, Rabasa-Lhoret R, Roden M, Scherer PE, Klein S, Ravussin E. Metabolically healthy and unhealthy obese: the 2013 Stock Conference report. Obes Rev 2014;15:697-708.

25. Popa SGG, Mitrea A, Rotaru A, Mota E, Mota M. Metabolically healthy obese and metabolically unhealthy lean phenotypes. Diabetes 2014;63(Suppl 1):A518.

26. Montague CT, Prins JB, Sanders L, Zhang J, Sewter CP, Digby J, Byrne CD, O'Rahilly S. Depot-related gene expression in human subcutaneous and omental adipocytes. Diabetes 1998;47:138491.

27. Weisberg SP, McCann D, Desai M, Rosenbaum M, Leibel RL, Ferrante AW Jr. Obesity is associated with macrophage accumulation in adipose tissue. J Clin Invest 2003;112:1796-808.

28. Gealekman O, Guseva N, Hartigan C, Apotheker S, Gorgoglione M, Gurav K, Tran KV, Straubhaar J, Nicoloro S, Czech MP, Thompson M, Perugini RA, Corvera S. Depot-specific differences and insufficient subcutaneous adipose tissue angiogenesis in human obesity. Circulation 2011;123:186-94.

29. Tran TT, Yamamoto Y, Gesta S, Kahn CR. Beneficial effects of subcutaneous fat transplantation on metabolism. Cell Metab 2008;7:410-20.

30. Hocking SL, Stewart RL, Brandon AE, Suryana E, Stuart E, Baldwin EM, Kolumam GA, Modrusan Z, Junutula JR, Gunton JE, Medynskyj M, Blaber SP, Karsten E, Herbert BR, James DE, Cooney GJ, Swarbrick MM. Subcutaneous fat transplantation alleviates diet-induced glucose intolerance and inflammation in mice. Diabetologia 2015;58:1587-600.

31. Foster MT, Shi H, Seeley RJ, Woods SC. Removal of intra-abdominal visceral adipose tissue improves glucose tolerance in rats: role of hepatic triglyceride storage. Physiol Behav 2011; 104:845-54.

32. Hwang I, Jo K, Shin KC, Kim JI, Ji Y, Park YJ, Park J, Jeon YG, Ka S, Suk S, Noh HL, Choe SS, Alfadda AA, Kim JK, Kim S, 
Kim JB. GABA-stimulated adipose-derived stem cells suppress subcutaneous adipose inflammation in obesity. Proc Natl Acad Sci U S A 2019;116:11936-45.

33. Kim JI, Huh JY, Sohn JH, Choe SS, Lee YS, Lim CY, Jo A, Park SB, Han W, Kim JB. Lipid-overloaded enlarged adipocytes provoke insulin resistance independent of inflammation. Mol Cell Biol 2015;35:1686-99.

34. Joe AW, Yi L, Even Y, Vogl AW, Rossi FM. Depot-specific differences in adipogenic progenitor abundance and proliferative response to high-fat diet. Stem Cells 2009;27:2563-70.

35. Kim JI, Park J, Ji Y, Jo K, Han SM, Sohn JH, Shin KC, Han JS, Jeon YG, Nahmgoong H, Han KH, Kim J, Kim S, Choe SS, Kim JB. During adipocyte remodeling, lipid droplet configurations regulate insulin sensitivity through F-actin and G-actin reorganization. Mol Cell Biol 2019;39:e0210-19.

36. Kusminski CM, Holland WL, Sun K, Park J, Spurgin SB, Lin Y, Askew GR, Simcox JA, McClain DA, Li C, Scherer PE. MitoNEET-driven alterations in adipocyte mitochondrial activity reveal a crucial adaptive process that preserves insulin sensitivity in obesity. Nat Med 2012;18:1539-49.

37. Miyazaki Y, Mahankali A, Matsuda M, Mahankali S, Hardies J, Cusi K, Mandarino LJ, DeFronzo RA. Effect of pioglitazone on abdominal fat distribution and insulin sensitivity in type 2 diabetic patients. J Clin Endocrinol Metab 2002;87:2784-91.

38. Spiegelman BM. PPAR-gamma: adipogenic regulator and thiazolidinedione receptor. Diabetes 1998;47:507-14.

39. Sohn JH, Kim JI, Jeon YG, Park J, Kim JB. Effects of three thiazolidinediones on metabolic regulation and cold-induced thermogenesis. Mol Cells 2018;41:900-8.

40. Zhang Y, Proenca R, Maffei M, Barone M, Leopold L, Friedman JM. Positional cloning of the mouse obese gene and its human homologue. Nature 1994;372:425-32.

41. Tsao TS, Murrey HE, Hug C, Lee DH, Lodish HF. Oligomerization state-dependent activation of NF-kappa B signaling pathway by adipocyte complement-related protein of $30 \mathrm{kDa}$ (Acrp30). J Biol Chem 2002;277:29359-62.

42. Tang QQ, Lane MD. Adipogenesis: from stem cell to adipocyte. Annu Rev Biochem 2012;81:715-36.

43. Kim JB, Spiegelman BM. ADD1/SREBP1 promotes adipocyte differentiation and gene expression linked to fatty acid metabolism. Genes Dev 1996;10:1096-107.

44. Rodeheffer MS, Birsoy K, Friedman JM. Identification of white adipocyte progenitor cells in vivo. Cell 2008;135:240-9.

45. Tang W, Zeve D, Suh JM, Bosnakovski D, Kyba M, Hammer RE, Tallquist MD, Graff JM. White fat progenitor cells reside in the adipose vasculature. Science 2008;322:583-6.

46. Wang QA, Tao C, Gupta RK, Scherer PE. Tracking adipogenesis during white adipose tissue development, expansion and regeneration. Nat Med 2013;19:1338-44.

47. Jeffery E, Church CD, Holtrup B, Colman L, Rodeheffer MS. Rapid depot-specific activation of adipocyte precursor cells at the onset of obesity. Nat Cell Biol 2015;17:376-85.

48. Chau YY, Bandiera R, Serrels A, Martinez-Estrada OM, Qing W, Lee M, Slight J, Thornburn A, Berry R, McHaffie S, Stimson RH, Walker BR, Chapuli RM, Schedl A, Hastie N. Visceral and subcutaneous fat have different origins and evidence supports a mesothelial source. Nat Cell Biol 2014;16:367-75.

49. Gupta OT, Gupta RK. Visceral adipose tissue mesothelial cells: living on the edge or just taking up space? Trends Endocrinol Metab 2015;26:515-23.

50. Merrick D, Sakers A, Irgebay Z, Okada C, Calvert C, Morley MP, Percec I, Seale P. Identification of a mesenchymal progenitor cell hierarchy in adipose tissue. Science 2019;364:eaav2501.

51. Burl RB, Ramseyer VD, Rondini EA, Pique-Regi R, Lee YH, Granneman JG. Deconstructing adipogenesis induced by $\beta 3$ adrenergic receptor activation with single-cell expression profiling. Cell Metab 2018;28:300-9.

52. Schwalie PC, Dong H, Zachara M, Russeil J, Alpern D, Akchiche N, Caprara C, Sun W, Schlaudraff KU, Soldati G, Wolfrum C, Deplancke B. A stromal cell population that inhibits adipogenesis in mammalian fat depots. Nature 2018;559:103-8.

53. Hotamisligil GS, Shargill NS, Spiegelman BM. Adipose expression of tumor necrosis factor-alpha: direct role in obesitylinked insulin resistance. Science 1993;259:87-91.

54. Tilg H, Moschen AR. Adipocytokines: mediators linking adipose tissue, inflammation and immunity. Nat Rev Immunol 2006;6:772-83.

55. Hotamisligil GS. Inflammation and metabolic disorders. Nature 2006;444:860-7.

56. Lago F, Dieguez C, Gomez-Reino J, Gualillo O. Adipokines as emerging mediators of immune response and inflammation. Nat Clin Pract Rheumatol 2007;3:716-24.

57. Huh JY, Kim JI, Park YJ, Hwang IJ, Lee YS, Sohn JH, Lee SK, Alfadda AA, Kim SS, Choi SH, Lee DS, Park SH, Seong RH, Choi CS, Kim JB. A novel function of adipocytes in lipid antigen presentation to iNKT cells. Mol Cell Biol 2013;33:328-39.

58. Wu L, Parekh VV, Gabriel CL, Bracy DP, Marks-Shulman PA, Tamboli RA, Kim S, Mendez-Fernandez YV, Besra GS, Lomenick JP, Williams B, Wasserman DH, Van Kaer L. Activation of invariant natural killer $\mathrm{T}$ cells by lipid excess promotes tissue 
inflammation, insulin resistance, and hepatic steatosis in obese mice. Proc Natl Acad Sci U S A 2012;109:E1143-52.

59. Lynch L, Nowak M, Varghese B, Clark J, Hogan AE, Toxavidis V, Balk SP, O'Shea D, O'Farrelly C, Exley MA. Adipose tissue invariant NKT cells protect against diet-induced obesity and metabolic disorder through regulatory cytokine production. Immunity 2012;37:574-87.

60. Ji Y, Sun S, Xia S, Yang L, Li X, Qi L. Short term high fat diet challenge promotes alternative macrophage polarization in adipose tissue via natural killer $\mathrm{T}$ cells and interleukin-4. J Biol Chem 2012;287:24378-86.

61. Feuerer M, Herrero L, Cipolletta D, Naaz A, Wong J, Nayer A, Lee J, Goldfine AB, Benoist C, Shoelson S, Mathis D. Lean, but not obese, fat is enriched for a unique population of regulatory T cells that affect metabolic parameters. Nat Med 2009;15:9309.

62. Lee EH, Itan M, Jang J, Gu HJ, Rozenberg P, Mingler MK, Wen T, Yoon J, Park SY, Roh JY, Choi CS, Park WJ, Munitz A, Jung Y. Eosinophils support adipocyte maturation and promote glucose tolerance in obesity. Sci Rep 2018;8:9894.

63. Zhang Y, Yang P, Cui R, Zhang M, Li H, Qian C, Sheng C, Qu S, $\mathrm{Bu}$ L. Eosinophils reduce chronic inflammation in adipose tissue by secreting Th2 cytokines and promoting M2 macrophages polarization. Int J Endocrinol 2015;2015:565760.

64. Huh JY, Park J, Kim JI, Park YJ, Lee YK, Kim JB. Deletion of $\mathrm{CD} 1 \mathrm{~d}$ in adipocytes aggravates adipose tissue inflammation and insulin resistance in obesity. Diabetes 2017;66:835-47.

65. Park J, Huh JY, Oh J, Kim JI, Han SM, Shin KC, Jeon YG, Choe SS, Park J, Kim JB. Activation of invariant natural killer T cells stimulates adipose tissue remodeling via adipocyte death and birth in obesity. Genes Dev 2019 In Press.

66. Lumeng CN, Bodzin JL, Saltiel AR. Obesity induces a phenotypic switch in adipose tissue macrophage polarization. J Clin Invest 2007;117:175-84.

67. Nishimura S, Manabe I, Nagasaki M, Eto K, Yamashita H, Ohsugi M, Otsu M, Hara K, Ueki K, Sugiura S, Yoshimura K, Kadowaki T, Nagai R. CD8+ effector T cells contribute to macrophage recruitment and adipose tissue inflammation in obesity. Nat Med 2009;15:914-20.

68. Winer DA, Winer S, Chng MH, Shen L, Engleman EG. B Lymphocytes in obesity-related adipose tissue inflammation and insulin resistance. Cell Mol Life Sci 2014;71:1033-43.

69. Xu H, Barnes GT, Yang Q, Tan G, Yang D, Chou CJ, Sole J, Nichols A, Ross JS, Tartaglia LA, Chen H. Chronic inflammation in fat plays a crucial role in the development of obesity-re- lated insulin resistance. J Clin Invest 2003;112:1821-30.

70. Winer DA, Winer S, Shen L, Wadia PP, Yantha J, Paltser G, Tsui H, Wu P, Davidson MG, Alonso MN, Leong HX, Glassford A, Caimol M, Kenkel JA, Tedder TF, McLaughlin T, Miklos DB, Dosch HM, Engleman EG. B cells promote insulin resistance through modulation of $\mathrm{T}$ cells and production of pathogenic IgG antibodies. Nat Med 2011;17:610-7.

71. Khan T, Muise ES, Iyengar P, Wang ZV, Chandalia M, Abate N, Zhang BB, Bonaldo P, Chua S, Scherer PE. Metabolic dysregulation and adipose tissue fibrosis: role of collagen VI. Mol Cell Biol 2009;29:1575-91.

72. Rui L, Aguirre V, Kim JK, Shulman GI, Lee A, Corbould A, Dunaif A, White MF. Insulin/IGF-1 and TNF-alpha stimulate phosphorylation of IRS-1 at inhibitory Ser307 via distinct pathways. J Clin Invest 2001;107:181-9.

73. Lee YS, Kim JW, Osborne O, Oh DY, Sasik R, Schenk S, Chen A, Chung H, Murphy A, Watkins SM, Quehenberger O, Johnson RS, Olefsky JM. Increased adipocyte $\mathrm{O} 2$ consumption triggers HIF-1 $\alpha$, causing inflammation and insulin resistance in obesity. Cell 2014;157:1339-52.

74. Choe SS, Shin KC, Ka S, Lee YK, Chun JS, Kim JB. Macrophage HIF- $2 \alpha$ ameliorates adipose tissue inflammation and insulin resistance in obesity. Diabetes 2014;63:3359-71.

75. Ham M, Lee JW, Choi AH, Jang H, Choi G, Park J, Kozuka C, Sears DD, Masuzaki H, Kim JB. Macrophage glucose-6-phosphate dehydrogenase stimulates proinflammatory responses with oxidative stress. Mol Cell Biol 2013;33:2425-35.

76. Shin KC, Hwang I, Choe SS, Park J, Ji Y, Kim JI, Lee GY, Choi SH, Ching J, Kovalik JP, Kim JB. Macrophage VLDLR mediates obesity-induced insulin resistance with adipose tissue inflammation. Nat Commun 2017;8:1087.

77. Cartier A, Lemieux I, Almeras N, Tremblay A, Bergeron J, Despres JP. Visceral obesity and plasma glucose-insulin homeostasis: contributions of interleukin-6 and tumor necrosis factor-alpha in men. J Clin Endocrinol Metab 2008;93:1931-8.

78. Lee YS, Li P, Huh JY, Hwang IJ, Lu M, Kim JI, Ham M, Talukdar S, Chen A, Lu WJ, Bandyopadhyay GK, Schwendener R, Olefsky J, Kim JB. Inflammation is necessary for long-term but not short-term high-fat diet-induced insulin resistance. Diabetes 2011;60:2474-83.

79. Lee BC, Kim MS, Pae M, Yamamoto Y, Eberle D, Shimada T, Kamei N, Park HS, Sasorith S, Woo JR, You J, Mosher W, Brady HJ, Shoelson SE, Lee J. Adipose natural killer cells regulate adipose tissue macrophages to promote insulin resistance in obesity. Cell Metab 2016;23:685-98. 
80. Sun K, Tordjman J, Clement K, Scherer PE. Fibrosis and adipose tissue dysfunction. Cell Metab 2013;18:470-7.

81. Iwayama T, Steele C, Yao L, Dozmorov MG, Karamichos D, Wren JD, Olson LE. PDGFRa signaling drives adipose tissue fibrosis by targeting progenitor cell plasticity. Genes Dev 2015; 29:1106-19.

82. Marcelin G, Ferreira A, Liu Y, Atlan M, Aron-Wisnewsky J, Pelloux V, Botbol Y, Ambrosini M, Fradet M, Rouault C, Henegar C, Hulot JS, Poitou C, Torcivia A, Nail-Barthelemy R, Bichet JC, Gautier EL, Clement K. A PDGFRa-mediated switch toward CD9(high) adipocyte progenitors controls obesity-induced adipose tissue fibrosis. Cell Metab 2017;25:673-85.

83. Hepler C, Shan B, Zhang Q, Henry GH, Shao M, Vishvanath L, Ghaben AL, Mobley AB, Strand D, Hon GC, Gupta RK. Identification of functionally distinct fibro-inflammatory and adipogenic stromal subpopulations in visceral adipose tissue of adult mice. Elife 2018;7:e39636.

84. Schuler V, Luscher C, Blanchet C, Klix N, Sansig G, Klebs K, Schmutz M, Heid J, Gentry C, Urban L, Fox A, Spooren W, Jaton AL, Vigouret J, Pozza M, Kelly PH, Mosbacher J, Froestl W, Kaslin E, Korn R, Bischoff S, Kaupmann K, van der Putten H, Bettler B. Epilepsy, hyperalgesia, impaired memory, and loss of pre- and postsynaptic $\mathrm{GABA}(\mathrm{B})$ responses in mice lacking GABA(B(1)). Neuron 2001;31:47-58.

85. Magnaghi V, Ballabio M, Camozzi F, Colleoni M, Consoli A, Gassmann M, Lauria G, Motta M, Procacci P, Trovato AE, Bettler B. Altered peripheral myelination in mice lacking GABAB receptors. Mol Cell Neurosci 2008;37:599-609.

86. Sekiya I, Larson BL, Vuoristo JT, Cui JG, Prockop DJ. Adipogenic differentiation of human adult stem cells from bone marrow stroma (MSCs). J Bone Miner Res 2004;19:256-64.

87. Koulnis M, Pop R, Porpiglia E, Shearstone JR, Hidalgo D, Socolovsky M. Identification and analysis of mouse erythroid progenitors using the CD71/TER119 flow-cytometric assay. J Vis Exp 2011;54:e2809.

88. Lee YH, Petkova AP, Mottillo EP, Granneman JG. In vivo identification of bipotential adipocyte progenitors recruited by $\beta 3$ adrenoceptor activation and high-fat feeding. Cell Metab 2012; 15:480-91.

89. Lee YH, Petkova AP, Granneman JG. Identification of an adipogenic niche for adipose tissue remodeling and restoration. Cell Metab 2013;18:355-67.

90. Spallanzani RG, Zemmour D, Xiao T, Jayewickreme T, Li C, Bryce PJ, Benoist C, Mathis D. Distinct immunocyte-promoting and adipocyte-generating stromal components coordinate adipose tissue immune and metabolic tenors. Sci Immunol 2019; 4:eaaw3658.

91. Tang Y, Qian SW, Wu MY, Wang J, Lu P, Li X, Huang HY, Guo L, Sun X, Xu CJ, Tang QQ. BMP4 mediates the interplay between adipogenesis and angiogenesis during expansion of subcutaneous white adipose tissue. J Mol Cell Biol 2016;8:302-12.

92. Cao Y. Angiogenesis modulates adipogenesis and obesity. J Clin Invest 2007;117:2362-8. 